\title{
CONTRIBUIÇÃO AO PLANEJAMENTO DE RECURSOS HÍDRICOS EM BACIAHIDROGRÁFICA: GEOMORFOLOGIA E FRAGILIDADE GEOAMBIENTAL DA UGRH PARANAPANEMA
}

\author{
Isabel Cristina Moroz-Caccia Gouveia ${ }^{1}$ \\ Antonio Cezar Leal ${ }^{2}$ \\ Letícia Roberta Trombeta ${ }^{3}$ \\ Rafael da Silva Nunes ${ }^{4}$ \\ Vinícius Bonafin Stoqui ${ }^{5}$
}

\begin{abstract}
Resumo: A gestão de bacias compartilhadas constitui um dos desafios na implementação dos instrumentos da Política Nacional de Recursos Hídricos no Brasil, necessitando de estudos detalhados, coordenação política e cooperação entre os participantes para que seja plenamente efetivada. Além de entraves relacionados a conflitos de interesses entre as unidades políticas usuárias desses recursos, o planejamento e a gestão de bacias hidrográficas que abrangem territórios de mais de um Município ou Estado da Federação Brasileira, se reveste de complexidade em função de questões peculiares relacionadas à articulação dos conhecimentos técnico-científicos disponíveis. Nesse sentido, a elaboração do Mapa Geomorfológico e do Mapa de Fragilidade Geoambiental da Unidade de Gestão de Recursos Hídricos Paranapanema com o objetivo principal de contribuir com as ações do CBH Paranapanema voltadas ao planejamento de recursos hídricos, exemplificam o desafio de integração de estudos produzidos com níveis de detalhamento diferenciados, decorrentes de procedimentos técnico-operacionais distintos. Assim, este artigo apresenta à comunidade geográfica os caminhos percorridos $e$ as soluções encontradas para a compatibilização $e$ integração de documentos cartográficos pré-existentes tais como o Mapa Geomorfológico do Estado de São Paulo, o Mapa Geomorfológico do Estado do Paraná e o Mapa de Vulnerabilidade Geoambiental do Estado do Paraná.
\end{abstract}

Palavras-Chave: Planejamento; Bacias Hidrográficas; Geomorfologia; Fragilidade Geoambiental.

\section{Contribution to the planning of water resources in watershed: geomorphology and geoenvironmental fragility UGRH Paranapanema}

\begin{abstract}
The management of shared basins is one of the challenges in implementing the instruments of the National Water Resources Policy in Brazil, requiring detailed studies, policy coordination and cooperation between the participants to be fully effective. In addition to barriers related to conflicts of interest among users polities such resources, planning and management of the watershed covering the territory of more than one municipality or state

\footnotetext{
1 Professora Assistente Doutora, Faculdade de Ciências e Tecnologia, Universidade Estadual Paulista Júlio de Mesquita Filho (UNESP)campus de Presidente Prudente, Departamento de Geografia. E-mail: icmoroz@fct.unesp.br

${ }^{2}$ Professor Assistente Doutor, Faculdade de Ciências e Tecnologia, Universidade Estadual Paulista Júlio de Mesquita Filho (UNESP)campus de Presidente Prudente, Departamento de Geografia. Pesquisador PQ/CNPq e Pesquisador colaborador do IG/UNICAMP. E-mail: cezar@fct.unesp.br

${ }^{3}$ Bacharel em Geografia e mestranda no Programa de Pós-Graduação em Geografia, Faculdade de Ciências e Tecnologia, Universidade Estadual Paulista Júlio de Mesquita Filho (UNESP)campus de Presidente Prudente. E-mail: leticiaroberta89@hotmail.com

${ }^{4}$ Graduando em Engenharia Cartográfica, Faculdade de Ciências e Tecnologia,Universidade Estadual Paulista Júlio de Mesquita Filho (UNESP) campus de Presidente Prudente. E-mail: rafaelsilv@gmail.com

${ }^{5}$ Graduando em Geografia, Faculdade de Ciências e Tecnologia, Universidade Estadual Paulista Júlio de Mesquita Filho (UNESP)campus de Presidente Prudente. E-mail: vinicius.stoqui@yahoo.com.br
} 
of the Brazilian Federation, is of complexity based on peculiar issues related to the articulation of available technical and scientific knowledge. Thus, the elaboration of Geomorphological Map and the Geoenvironmental Fragility Map of Paranapanema Water Resources Management Unit with the main objective of contributing to the shares of $\mathrm{CBH}$ Paranapanema focused on the planning of water resources, exemplify the integration challenge studies produced with different levels of detail, resulting from different technical and operational procedures. This article presents for the geographic community the paths taken and solutions found for compatibility and integration of pre-existing cartographic documents, such as the Geomorphological Map of the São Paulo State, Geomorphological Map of the Paraná State and GeoenvironmentalVulnerability Map of the Paraná State.

Keywords: Planning; Watershed; Geomorphology; Geoenvironmental fragility.

\section{INTRODUÇÃO}

A gestão dos recursos hídricos em bacias hidrográficas tem como principal instrumento oplanejamento e este constitui uma das primeiras providências dos Comitês de Bacias Hidrográficas Estaduais ou Interestaduais. Para tanto, devem ser atendidas as normas legais e técnicas, garantindo-se participação social no processo de planejamento e a articulação do plano com os demais instrumentos de gerenciamento de recursos hídricos e de gestão ambiental, especialmente a outorga de direito de uso, a cobrança pelo uso dos recursos hídricos, o enquadramento dos corpos hídricos, o licenciamento ambiental, o zoneamento ecológico-econômico e o Código Florestal (Lei 12.651/2012).

De acordo com a Lei das Águas (Lei Federal no 9.433/1997), os planos de recursos hídricos constituem planos diretores que visam a fundamentar e orientar a implementação da Política Nacional de Recursos Hídricos, os quais devem ser de longo prazo, permitindo a execução dos programas e projetos estabelecidos e a consecução dos objetivos propostos, valorizando-se o processo de planejamento, de forma participativa, descentralizada e democrática.

Reafirmando essa definição, o Conselho Nacional de Recursos Hídricos estabeleceu na Resolução CNRH 145/2012(BRASIL-CNRH, 2012) as diretrizes para a elaboração de Planos de Recursos Hídricos de Bacias Hidrográficas, as quais devem ser aplicadas às regiões hidrográficas estabelecidas na Resolução CNRH 32/2003(BRASIL-CNRH, 2003), na qual "considera-se como região hidrográfica o espaço territorial brasileiro compreendido por uma bacia, grupo de bacias ou sub-bacias hidrográficas contíguas com características naturais, 
sociais e econômicas homogêneas ou similares, com vistas a orientar o planejamento e gerenciamento dos recursos hídricos".

Os Planos de Recursos Hídricos de Bacias Hidrográficas, de acordo com a Resolução CNRH 145/2012, "deverão ser constituídos pelas etapas de diagnóstico, prognóstico e plano de ações, contemplando os recursos hídricos superficiais e subterrâneos e estabelecendo metas de curto, médio e longo prazos e ações para seu alcance, observando o art. 7ำ da Lei $n^{\circ}$ 9.433, de 1997". Embora prevendo que o conteúdo dos Planos "deverá ser estabelecido em Termo de Referência específico, construído a partir da articulação entre a entidade gestora de recursos hídricos e o Comitê de Bacia, quando ele existir, considerando as especificidades da bacia hidrográfica", nessa Resolução foram estabelecidos os conteúdos mínimos para o Diagnóstico, o Prognóstico e o Plano de Ação.

Nesse sentido, e com o objetivo de orientar a criação de Comitês de Bacia e a implantação dos instrumentos da Política Nacional de Recursos Hídricos, o CNRH já havia aprovado a Resolução 109/2010, na qual foram definidas as Unidades de Gestão de Recursos Hídricos de Bacias Hidrográficas de rios de domínio da União (UGRH). Dentre essas, foi definida a UGRH Paranapanema, que abrange terras dos Estados do Paraná e de São Paulo, com 105.921 km², dos quais $51.833 \mathrm{~km}^{2}(48,94 \%)$ encontram-se dentro do Estado de São Paulo, perfazendo 20,88\% do território paulista; e $54.088 \mathrm{~km}^{2}$ (51,06\%) no Estado do Paraná, com aproximadamente 27,53\% da área desse Estado (SÃO PAULO; PARANÁ, 2010).

Para a gestão dos recursos hídricos dessa UGRH, foi criado, em dezembro de 2012, o Comitê da Bacia Hidrográfica do Rio Paranapanema (CBH Paranapanema), resultante de um processo de articulação institucional e de mobilização social que envolveu a União, os Estados de São Paulo e do Paraná, através de seus órgãos gestores de recursos hídricos, prefeituras municipais, usuários de recursos hídricos e entidades civis com atuação nesta unidade hidrográfica, superando inúmeros desafios presentes na constituição de um Comitê de Bacia Hidrográfica Interestadual.

Dentre esses desafios,alguns se fizeram presentes já nos procedimentos técnicosoperacionais e em estudos iniciais que subsidiaram a elaboração dosdocumentos apresentados ao CNRH para aprovar a criação do CBH-Paranapanema. ${ }^{6}$

Segundo Leal (2012),

No intuito de contribuir para as ações do GT-Paranapanema foram realizados estudos junto ao GADIS/UNESP, que incluíram a elaboração de

${ }^{6}$ Esses estudos estão disponíveis em http://www.paranapanema.org 
mapas temáticos, compilando e atualizando mapas, informações e dados existentes em órgãos públicos. Para sua elaboração, uma das atividades centrais foi a organização de dados e de bases cartográficas da UGRH Paranapanema, tarefa também enfrentada pelo GT-Paranapanema, com dificuldades operacionais tendo em vista a existência de diferentes procedimentos técnicos nos entes da Federação envolvidos. Assim, a organização de um mapa base demandou tempo razoável para reunir informações cartográficas em diferentes formatos e escalas, bem como para a identificação de municípios parcialmente contidos nessa UGRH. ( $p$. 232)

Dificuldades semelhantes, decorrentes da existência de diferentes procedimentos técnicos, também foram verificadas em etapas posteriores à elaboração do mapa base, quando se iniciaram os trabalhos de compilação e elaboração dos mapas temáticos.Embora os estados de São Paulo e Paraná possuam estudos e mapeamentos temáticos, sobretudo relacionados ao meio físico (geologia, geomorfologia, solos, clima, dentre outros) tais produtos, de um modo geral, não foram elaborados nas mesmas escalas e seguindo procedimentos metodológicos iguais. Mesmo os poucos produtos elaborados de acordo a mesma metodologia, como é o caso dos mapas geomorfológicos dos estados de São Paulo e Paraná, exigiram esforços para a compatibilização de conteúdos e legendas, em função de escalas diferentes e de níveis de detalhamento diferenciados, decorrentes dos procedimentos técnicos-operacionais adotados na elaboração de cada produto.

Nesse contexto, somando-se às ações em andamento pelo CBH-Paranapanemae pela Agência Nacional de Águas (ANA) para o planejamento dos recursos hídricos na UGRH Paranapanema, e tendo em vista os conteúdos exigidos na Resolução CNRH 145/2012(BRASIL-CNRH, 2012)e na Deliberação CRH 146/2012, do Conselho Estadual de Recursos Hídricos de São Paulo (SÃO PAULO-CRH, 2012), foram retomados os estudos para a elaboração de mapa geomorfológico e de fragilidade geoambientaldesta unidade hidrográfica, objetivando contribuir para seu planejamento, notadamente nas etapas de caracterização e deidentificação de áreas sujeitas a gestão especial.

De acordo com a Resolução CNRH 145/2012, que estabelece que os estudos necessários à elaboração de Planos de Recursos Hídricos de Bacias Hidrográficas sejam elaborados a partir dos dados secundários disponíveis, a ideia inicial era a simples junção dos produtos cartográficos pré-existente. Entretanto, as incongruências observadas nas áreas limítrofes demandaram uma reorganização cartográfica que implicou ora na generalização de algumas informações, ora na inserção de novas informações. Assim, a elaboração do Mapa Geomorfológico e do Mapa de Fragilidade Geoambiental da UGRH Paranapanema consistiu 
basicamente em um trabalho de gabinete, utilizando-se de dados secundários, mas contemplou também a análise e interpretação de mosaicos de imagens de radar analógicas (Projeto Radambrasil, 1976), de Modelo Digitação de Elevação do terreno (MDE) elaborado apartir de imagens SRTM e análises de mapas geológicos para a validação de generalizações ou detalhamentos realizados.

\section{A importância dos estudos geomorfológicos no planejamento}

Ross eMoroz (1997) ressaltam que a Geomorfologia desempenha papel importante no planejamento do uso da terra para a agricultura, pecuária, urbanização, planejamento ambiental, pesquisas sobre recursos minerais, recuperação de áreas degradadas, dentre outras.

De acordo com Girão e Corrêa (2004),

A apropriação do espaço pela sociedade evidencia a importância do relevo como fator de natureza antagônica, ora favorável à ocupação, ora apresentando feições e processos que desencorajam o mecanismo de ocupação por grupos humanos. Assim, o relevo tem um caráter restritivo a determinados tipos de ocupação humana. Entretanto, é inegável que o relevo constitui-se em um elemento basilar para a expansão da humanidade, pois se apresenta como forma de suprir as necessidades primordiais de ocupação ou exploração de recursos de determinada área que, invariavelmente, acarretam alterações no estado original da mesma. (p.39)

Desse modo, os conhecimentos relativos à Geomorfologia são de suma importância para o desenvolvimento de projetos de planejamento aplicáveis aos estudos ambientais, ao ordenamento ou disciplinamento do uso da terra em áreas urbanas ou rurais, pesquisas relacionadas a recursos naturais renováveis e não renováveis, bem como à prevenção ou recuperação de áreas afetadas por impactos de cunho antropogenético. (CHRISTOFOLETTI, 1994; SUGUIO, 2000).

Girão e Corrêa (2004) destacam que no contexto de um espaço geográfico, onde a interação de mecanismos naturais e sociais responde pela dinâmica espacial propriamente dita, o conhecimento geomorfológico surge como instrumental de grande relevância estando, invariavelmente, inserido na execução de diversas categorias setoriais de planejamento. Dentre inúmeros exemplos, destaca-se a aplicabilidade dos estudos geomorfológicos em projetos para a implantação de usinas hidro e termoelétricas, no planejamento do uso do 
solo rural ou do solo urbano, nas obras de engenharia (rodovias e ferrovias), no planejamento ambiental, na pesquisa de recursos minerais e recuperação de áreas degradadas por mineração, e na classificação de terrenos (CHRISTOFOLETTI, 1994; ROSS, 1990).

Rodrigues (1997) afirma que "planejar é antecipar cenários sobre processos" (p.126). Assim, as previsões em geomorfologia estão diretamente ligadas aos objetivos nucleares do planejamento físico-territorial e ambiental, tais como avaliação de recursos, avaliação de impactos, e prevenção de riscos. Avaliar recursos implica em previsões, em simular respostas sobre o comportamento do meio físico diante das solicitações de exploração. Da mesma forma, avaliar impactos também implica na antecipação sobre o comportamento do ambiente diante de solicitações específicas. A prevenção de riscos ambientais trabalha necessariamente com previsão, necessitando do conhecimento da morfodinâmica para realizar antecipações sobre processos. Entretanto, nesse caso, não basta apenas considerar a morfodinâmica natural, mas torna-se necessário reconhecer as combinações de ações antrópicas e características geomorfológicas que podem desencadear processos indesejáveis. Segundo Rodrigues (1997),

a aplicação do conhecimento da geomorfologia antropogênica ${ }^{7}$ se dá na prevenção, controle e recuperação de situações de riscos de degradação; na orientação para a manutenção de benfeitorias de infraestruturas e tipos de usos bem como na orientação para formas de manejo de conservação ambiental. (p. 124)

Ainda de acordo com a autora, "prever em geomorfologia não se refere simplesmente a antecipar-se no tempo quanto aos tipos de processos, mas a fornecer noções sobre onde, em que tempo, com que frequência e com que magnitude" (p.126).

Nesse sentido, a análise e cartografia geomorfológicas constituem instrumentais técnicos de fundamental importância para o ordenamento e gestão territorial, notadamente no contexto de planejamento de recursos hídricos em bacias hidrográficas.

\section{A contribuição dos mapas geomorfológicos na definição de Unidades da Paisagem}

Diversos autores (CHRISTIAN; STEWART, 1968; TRICART; KILIAN, 1979; DENT; YOUNG, 1981; FLORENZANO, 1986; COOKE; DOORKAMP, 1990; ROSS, 2006), ressaltam a importância da

\footnotetext{
${ }^{7}$ Proposta de abordagem que considera a interferência antrópica como ação geomorfológica. (NIR, 1981)
} 
Geomorfologia como elemento de integração de vários componentes da paisagem e como base na delimitação de suas unidades hierárquicas(FLORENZANO, 2008, p. 120).

Isso decorre, sobretudo, do fato das unidades de relevo refletirem, por si só, diversas interações dos componentes do meio físico e biótico e, em alguns casos, até mesmo dos componentes antrópicos.

De acordo com Ross (1990), as unidades de paisagem se diferenciam pelo relevo, clima, cobertura vegetal, solos e pelo arranjo estrutural e do tipo de litologia. Em alguns casos, a variação de apenas um desses componentes pode implicar em unidades de paisagem também diferenciadas. Como exemplo, o autor aponta que variações litológicas implicam em diferenças nas formas de relevo, na tipologia dos solos e, consequentemente, na composição da cobertura vegetal, sendo que esta última pode implicar ainda em interferências climáticas (ao menos no microclima), e na diferenciação e distribuição da fauna e microrganismos. (p. 12). Assim, as unidades de relevo expressam certas combinações entre litologias, solos e clima e refletem ainda as características das bacias hidrográficas, uma vez que a dissecação do relevo explicita a densidade e organização das drenagens.

Florenzano (2008) aponta um estudo de Gils (1989), no qual foram analisados o conteúdo e a estrutura da legenda de 50 mapas de unidades da paisagem (landscapeecologymaps) $e$ contatou-se que, na maior parte desses mapas, a Geomorfologia apareceu como a informação principal, no primeiro ou segundo nível da legenda, enquanto que os outros componentes, tais como a vegetação, solo e/ou uso do solo, figuravam em níveis inferiores da legenda, geralmente como unidades complexas.

Dentre os diversos métodos de classificação dos terrenos que utilizam uma abordagem integrada ou sistêmica, apoiada no conceito de paisagem, destacam-se, no Brasil, dois sistemas de mapeamento integrado que adotam as unidades de relevo como informação principal: Mapas de Fragilidade Ambiental (ROSS, 1994;1996) e Mapas de Vulnerabilidade à Erosão (CREPANI et al., 2001). Segundo Florenzano (2008), "ambos os sistemas vêm sendo utilizados na elaboração de zoneamentos ambientais, mais especificamente no Zoneamento Ecológico-Econômico (ZEE), como definido institucionalmente." (p. 122).

O Decreto № 4.297/2002, que estabeleceu critérios para o Zoneamento EcológicoEconômico do Brasil, definiu o ZEE, como

instrumento de organização do território a ser obrigatoriamente seguido na implantação de planos, obras e atividades públicas e privadas, estabelece 
medidas e padrões de proteção ambiental destinados a assegurar a qualidade ambiental, dos recursos hídricos e do solo e a conservação da biodiversidade, garantindo o desenvolvimento sustentável e a melhoria das condições de vida da população. (Artigo $2^{\circ}$ )

Nesse sentido, é importante integrar o ZEE com o planejamento de recursos hídricos em bacias hidrográficas, notadamente para a definição de áreas sujeitas a gestão especial e controle do uso e ocupação das terras para evitar impactos negativos nas águas.

\section{A elaboração do Mapa Geomorfológico da UGRH Paranapanema em escala 1:650.000}

O Mapa Geomorfológico da UGRH Paranapanema, (Figura 1), foi elaborado a partir da junção e compatibilização do Mapa Geomorfológico do Estado de São Paulo, em escala 1:500.000 (ROSS; MOROZ, 1997) e do Mapa Geomorfológico do Estado do Paraná, em escala 1:650.000 (OKA-FIORI et al., 2006; SANTOS et al., 2006). Ressalta-se que embora a proposta de elaboração dos mapas temáticos para a UGRH Paranapanema contemple a escala de 1:1.000.000, no caso do mapa geomorfológico, optou-se por manter as informações compatíveis com a escala de 1:650.000, dada a importância e relevância dos atributos geomorfológicos para a definição de Unidades da Paisagem e o planejamento da bacia hidrográfica.

Embora os dois mapas tenham sido elaborados de acordo com a mesma metodologia, fundamentada nos conceitos de morfoestrutura e morfoescultura, definida com base nos trabalhos de classificação e taxonomia do relevo de Ross (1992), a junção dos dois mapas necessitou de ajustes para a compatibilização das informações pelo seguinte motivo:

- o Mapa do Geomorfológico do Estado de São Paulo foi elaborado, em 1996, a partir da análise e interpretação visual de imagens analógicas de radar (Mosaicos semi controlados do Projeto Radambrasil), em escala 1:250.000, da década de 1970. Já o Mapa Geomorfológico do Estado do Paraná, elaborado, em 2006, a partir dedados do Radar SRTM (Shuttle Radar TopographyMission), do ano 2000, com resolução de 90 metros, obtidos do site da NASA.

O Mapa Geomorfológico do Estado do Paraná foi disponibilizado em arquivos compatíveis com ambiente SIG, especificamente, no formato shapefile. Entretanto, como o Mapa Geomorfológico do Estado de São Paulo, foi disponibilizado apenas em formato $d w g$, demandou o trabalho de conversão das informações (atributos) em shapefile. Foram necessários, também, ajustes de georeferenciamento. 
- O processo de elaboração do Mapa Geomorfológico daUGRH Paranapanema baseou-se na compilação de dados secundários, que constam nos mapas geomorfológicos do Estado de São Paulo e Paraná, sendo a validação desses dados realizada com a utilização do Modelo Digital de Elevação, das imagens de radar do projeto Radambrasil, de imagens de satélite para visualização, disponíveis na interface online do ArcGis $10^{\circledR}$ e mapas geológicos do IPT (1981) e Mineropar (2001).

Como a base cartográfica original do mapa geomorfológico do Estado de São Paulo está em formato $d w g$, esta foi convertida para o formato shapefile eforam inseridas as informações dos nomes e do identificador numérico para cada unidade geomorfológica, bem como a correção dos polígonos. Como os arquivos originais não estavam georreferenciados, este procedimento foi realizado a partir da sobreposição com a base cartografia georreferenciada dos limites estaduais e municipais do Instituto Brasileiro de Geografia (IBGE) e com o grid de coordenadas do arquivo original.

Para a verificação e validação das unidades geomorfológicas utilizou-se um Modelo Digital de Elevação que foi obtido com os dados do SRTM, com resolução espacial de 90 metros. No entanto, a fim de melhorar a sua apresentação, este foi interpolado utilizando a ferramenta Spline do ArcGis $10^{\circledR}$, gerando um novo modelo com pixel de 30 metros. Foi produzido através deste último, um modelo sombreado do relevo (hillshade) da área para a verificação dos compartimentos geomorfológicos, sendo esses procedimentos realizados no $\operatorname{ArcGis} 10^{\circledR}$. Finalizadas essas etapas, procedeu-se à junção dos dois documentos cartográficos e observou-se que na vertente paulista do médio e baixo curso do Rio Paranapanema, a unidade morfoescultural denominada Planalto Ocidental Paulista, apresentava apenas duas sub-unidades: o Planalto Residual de Marília, de expressão espacial bastante restrita e o Planalto Centro Ocidental, ocupando vasta área. Já a unidade morfoescultural correspondente na vertente paranaense (Terceiro Planalto Paranaense), apresentava seis sub-unidades. A fim de aproximar o nível de detalhamento do Mapa Geomorfológico de São Paulo àquele adotado no Mapa Geomorfológico do Paraná, foram feitas as seguintes modificações: 


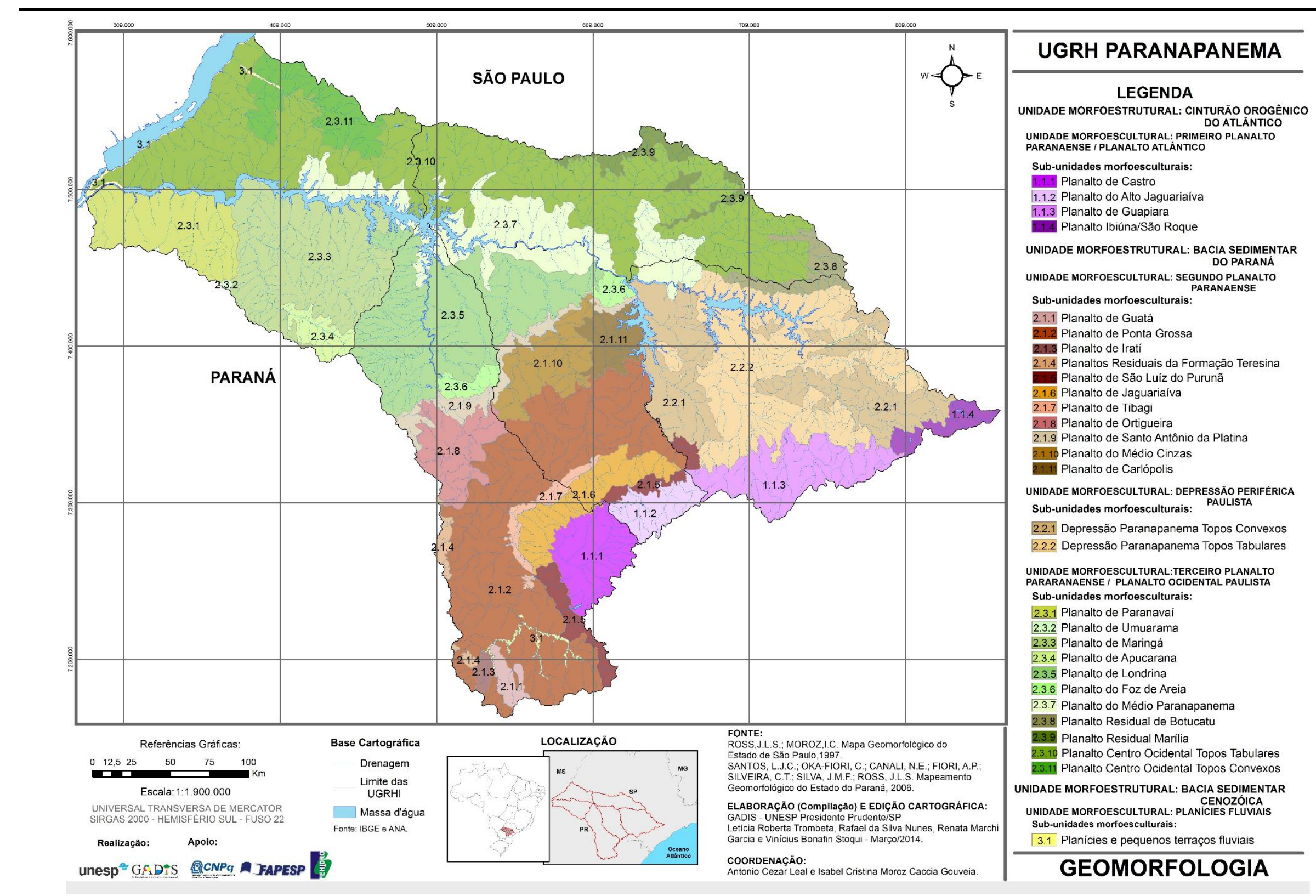

Figura 1 - Mapa Geomorfológico da UGRH Paranapanema 
CONTRIBUIÇÃO AO PLANEJAMENTO DE RECURSOS HÍDRICOS EM BACIA HIDROGRÁFICA: GEOMORFOLOGIA E FRAGILIDADE GEOAMBIENTAL DA UGRH PARANAPANEMA Isabel Cristina Moroz-Caccia Gouveia, Antonio Cezar Leal, Letícia Roberta Trombeta, Rafael da Silva Nunes e Vinícius BonafinStoqui

\begin{tabular}{|c|c|c|c|c|c|c|}
\hline & & IDADE MORF & & & & \\
\hline \multicolumn{7}{|c|}{ UNIDADES MORFOESCULTURAIS Primeiro Planalto Paranaense/Planalto Atlântico } \\
\hline \multirow[t]{2}{*}{ Sub-unidadesMorfoesculturais } & \multicolumn{3}{|c|}{ Formas de Relevo } & & \multirow[t]{2}{*}{ Litologias dominantes } & \multirow{2}{*}{$\begin{array}{c}\text { Solos } \\
\text { dominantes }\end{array}$} \\
\hline & Modelados dominantes & Altimetrias & $\begin{array}{l}\text { Declividades } \\
\text { dominantes }\end{array}$ & $\begin{array}{l}\text { Dissecação } \\
\text { do relevo }\end{array}$ & & \\
\hline 1.1.1 Planalto de Castro & $\begin{array}{l}\text { Morros altos com topos alongados e } \\
\text { aplainados }\end{array}$ & 900 a $1300 m$ & $\begin{array}{l}<6 \% \\
6 \text { a } 30 \%\end{array}$ & Média & Complexo Granítico Cunhaporanga & Latossolos \\
\hline 1.1.2 Planalto do Alto Jaguariaíva & $\begin{array}{l}\text { Morros altos a médios com topos } \\
\text { alongados }\end{array}$ & 800 a $1300 m$ & $\begin{array}{l}<6 \% \\
6 \text { a } 30 \%\end{array}$ & Alta & Complexo Granítico Cunhaporanga & Argissolos \\
\hline 1.1.3 Planalto de Guapiara & $\begin{array}{l}\text { Morros médios com topos } \\
\text { suavemente convexizados }\end{array}$ & 700 a $800 m$ & 20 a $30 \%$ & $\begin{array}{l}\text { Média a } \\
\text { Alta }\end{array}$ & $\begin{array}{l}\text { Granitos (Suites Graníticas Sintectônicas), Filitos e Calcários (Grupo } \\
\text { Açungui) }\end{array}$ & Argissolos \\
\hline 1.1.4 Planalto Ibiúna/São Roque & $\begin{array}{l}\text { Morros altos com topos alongados } \\
\text { aguçados e convexizados }\end{array}$ & 800 a $1100 m$ & $\begin{array}{l}20 \text { a } 30 \% \text { e } \\
>30 \%\end{array}$ & $\begin{array}{l}\text { Média a } \\
\text { Alta }\end{array}$ & $\begin{array}{l}\text { Granitos (Suites Graníticas Sintectônicas), Gnaisses e Migmatitos } \\
\text { (Grupo São Roque) }\end{array}$ & $\begin{array}{l}\text { Argissolos e } \\
\text { Latossolos }\end{array}$ \\
\hline \multicolumn{7}{|c|}{ UNIDADE MORFOESTRUTURAL BACIA SEDIMENTAR DO PARANÁ } \\
\hline \multicolumn{7}{|c|}{ UNIDADES MORFOESCULTURAIS Segundo Planalto Paranaense/ Depressão Periférica Paulista } \\
\hline \multirow[t]{2}{*}{ Sub-unidadesMorfoesculturais } & \multicolumn{4}{|c|}{ Formas de Relevo } & \multirow[t]{2}{*}{ Litologias dominantes } & \multirow{2}{*}{$\begin{array}{l}\text { Solos } \\
\text { dominantes }\end{array}$} \\
\hline & Modelados dominantes & Altimetrias & $\begin{array}{l}\text { Declividades } \\
\text { dominantes }\end{array}$ & $\begin{array}{l}\text { Dissecação } \\
\text { do relevo }\end{array}$ & & \\
\hline 2.1.1 Planalto de Guatá & Colinas com topos alongados & 800 a $1000 m$ & $\begin{array}{l}<6 \% \text { e } \\
6 \text { a } 12 \%\end{array}$ & Alta & $\begin{array}{l}\text { Arenitos, tilitos, siltitos. Folhelhos, ritmitos e conglomerados (Grupo } \\
\text { Itararélndivisos) }\end{array}$ & Cambissolos \\
\hline 2.1.2 Planalto de Ponta Grossa & $\begin{array}{l}\text { Colinas e morrotes com topos } \\
\text { alongados }\end{array}$ & 500 a $1000 m$ & $\begin{array}{l}<6 \% \text { e } \\
6 \text { a } 30 \%\end{array}$ & Média & $\begin{array}{l}\text { Arenitos, tilitos, siltitos. Folhelhos, ritmitos e conglomerados (Grupo } \\
\text { Itararélndivisos) }\end{array}$ & Cambissolo \\
\hline 2.1.3 Planalto de Irati & $\begin{array}{l}\text { Colinas e morrotes com topos } \\
\text { alongados e isolados }\end{array}$ & 750 a $900 m$ & $\begin{array}{l}<6 \% \text { e } \\
6 \text { a } 30 \%\end{array}$ & Média & $\begin{array}{l}\text { Folhelhos, argilitos, siltitos e arenitos finos. Presença restrita de lentes } \\
\text { de calcários oolíticos e sílex (Formação Teresina) }\end{array}$ & Argissolos \\
\hline $\begin{array}{l}\text { 2.1.4 Planaltos Residuais da } \\
\text { Formação Teresina }\end{array}$ & Colinas com topos aplainados & 550 a $1100 m$ & $\begin{array}{l}<6 \% \text { e } \\
6 \text { a } 30 \%\end{array}$ & Baixa & $\begin{array}{l}\text { Folhelhos, argilitos, siltitos e arenitos finos. Presença restrita de lentes } \\
\text { de calcários oolíticos e sílex (Formação Teresina) }\end{array}$ & Argissolos \\
\hline $\begin{array}{l}\text { 2.1.5 Planalto de São Luis do } \\
\text { Purunã }\end{array}$ & Colinas com topos aplainados & 750 a $1300 m$ & $\begin{array}{l}<6 \% \text { e } \\
6 \text { a } 12 \%\end{array}$ & Baixa & Arenitos de granulação grossa e conglomerados (Formação Furnas) & Cambissolos \\
\hline 2.1.6 Planalto de Jaguariaíva & $\begin{array}{l}\text { Colinas e morros com topos } \\
\text { alongados }\end{array}$ & 600 a $1200 m$ & $\begin{array}{l}<6 \% \text { e } \\
6 \text { a } 12 \%\end{array}$ & Alta & Arenitos de granulação grossa e conglomerados (Formação Furnas) & Latossolos \\
\hline 2.1.7 Planalto do Tibagi & Colinas com topos aplainados & 600 a $1000 m$ & $\begin{array}{l}<6 \% \text { e } \\
6 \text { a } 12 \%\end{array}$ & Média & Siltitos e folhelhos (Formação Ponta Grossa) & Latossolos \\
\hline 2.1.8 Planalto de Ortigueira & $\begin{array}{l}\text { Colinas e morrotes com topos } \\
\text { alongados }\end{array}$ & 400 a $1100 m$ & $\begin{array}{l}<6 \% \text { e } \\
6 \text { a } 30 \%\end{array}$ & Alta & $\begin{array}{l}\text { Folhelhos, argilitos, siltitos e arenitos finos. Presença restrita de lentes } \\
\text { de calcários oolíticos e sílex (Formação Teresina) }\end{array}$ & Neossolos \\
\hline $\begin{array}{l}\text { 2.1.9 Planalto de Santo Antônio } \\
\text { da Platina }\end{array}$ & Morrotes com topos isolados & 400 a $1200 m$ & 6 a $12 \%$ & Alta & Arenitos finos, argilitos e siltitos (Formação Rio doRasto) & Neossolos \\
\hline 2.1.10 Planalto do Médio Cinzas & Colinas com topos aplainados & 450 a $700 m$ & $\begin{array}{l}<6 \% \mathrm{e} \\
6 \mathrm{a} 12 \%\end{array}$ & Baixa & $\begin{array}{l}\text { Folhelhos, argilitos, siltitos e arenitos finos. Presença restrita de lentes } \\
\text { de calcários oolíticos e sílex (Formação Teresina) }\end{array}$ & Argissolos \\
\hline 2.1.11 Planalto de Carlópolis & Colinas com topos aplainados & 500 a $800 m$ & $\begin{array}{l}<6 \% \text { e } \\
6 \text { a } 12 \%\end{array}$ & Média & $\begin{array}{l}\text { Arenitos finos, argilitos e siltitos (Formação Rio do } \\
\text { Rasto) }\end{array}$ & Argissolos \\
\hline $\begin{array}{l}\text { 2.2.1 Depressão Paranapanema } \\
\text { Topos convexos }\end{array}$ & Colinas com topos convexos & 600 a $800 m$ & 12 a $20 \%$ & Média & $\begin{array}{l}\text { Arenitos, conglomerados, siltitostilitos, folhelhos (Formação Itararé), e } \\
\text { arenitos finos a médios (Formação Pirambóia e Formação Botucatu) }\end{array}$ & $\begin{array}{l}\text { Argilosos e } \\
\text { NeossolosQuar } \\
\text { tzarênicos }\end{array}$ \\
\hline $\begin{array}{l}\text { 2.2.2 Depressão Paranapanema } \\
\text { Topos tabulares }\end{array}$ & Colinas com topos aplainados & 600 a $700 \mathrm{~m}$. & $\begin{array}{l}<6 \% \text { e } \\
6 \text { a } 12 \%\end{array}$ & Baixa & $\begin{array}{l}\text { Arenitos, conglomerados, siltitostilitos, folhelhos (Formação Itararé), e } \\
\text { arenitos finos a médios (Formação Pirambóia e Formação Botucatu) }\end{array}$ & $\begin{array}{l}\text { Latossolos e } \\
\text { Argissolos }\end{array}$ \\
\hline
\end{tabular}


CONTRIBUIÇÃo AO PLANEJAMENTO DE RECURSOS HÍDRICOS EM BACIA HIDROGRÁFICA: GEOMORFOLOGIA E FRAGILIDADE GEOAMBIENTAL DA UGRH PARANAPANEMA Isabel Cristina Moroz-Caccia Gouveia, Antonio Cezar Leal, Letícia Roberta Trombeta, Rafael da Silva Nunes e Vinícius BonafinStoqui

\begin{tabular}{|c|c|c|c|c|c|c|}
\hline \multicolumn{7}{|c|}{$\begin{array}{ll}\text { UNIDADE MORFOESTRUTURAL BACIA SEDIMENTAR DO PARANÁ } \\
\end{array}$} \\
\hline \multicolumn{7}{|c|}{ UNIDADES MORFOESCULTURAL Terceiro Planalto Paranaense/ Planalto Ocidental Paulista } \\
\hline \multirow[t]{2}{*}{ Sub-unidadesMorfoesculturais } & \multicolumn{4}{|c|}{ Formas de Relevo } & \multirow[b]{2}{*}{ Litologias dominantes } & \multirow[b]{2}{*}{$\begin{array}{l}\text { Solos } \\
\text { dominantes }\end{array}$} \\
\hline & Modelados dominantes & Altimetrias & $\begin{array}{l}\text { Declividades } \\
\text { dominantes }\end{array}$ & $\begin{array}{l}\text { Dissecação } \\
\text { do Relevo }\end{array}$ & & \\
\hline 2.3.1 Planalto de Paranavaí & Colinas com topos aplainados & 250 a $550 m$ & $\begin{array}{l}<6 \% \text { e } \\
6 \text { a } 12 \%\end{array}$ & Baixa & Arenitos finos a médios (Formação Caiuá) & Latossolos \\
\hline 2.3.2 Planalto de Umuarama & $\begin{array}{l}\text { Colinas com topos alongados e } \\
\text { aplainados }\end{array}$ & 250 a $650 \mathrm{~m}$ & $\begin{array}{l}<6 \% \text { e } \\
6 \text { a } 12 \%\end{array}$ & Média & Arenitos finos a médios Formação Caiuá & Argissolos \\
\hline 2.3.3 Planalto de Maringá & $\begin{array}{l}\text { Colinas com topos alongados e } \\
\text { aplainados }\end{array}$ & 250 a $800 \mathrm{~m}$ & $\begin{array}{l}<6 \% \text { e } \\
6 \text { a } 12 \%\end{array}$ & Baixa & $\begin{array}{l}\text { Basaltos com intercalados por arenitos intertrapeanos finos a médios } \\
\text { (Formação Serra Geral) }\end{array}$ & Latossolos \\
\hline 2.3.4 Planalto de Apucarana & $\begin{array}{l}\text { Colinas e morrotes com topos } \\
\text { alongados }\end{array}$ & 300 a $900 \mathrm{~m}$ & $\begin{array}{l}<6 \% \text { e } \\
6 \text { a } 12 \%\end{array}$ & Alta & $\begin{array}{l}\text { Basaltos com intercalados por arenitos intertrapeanos finos a médios } \\
\text { (Formação Serra Geral) }\end{array}$ & Nitossolos \\
\hline 2.3.5 Planalto de Londrina & $\begin{array}{l}\text { Colinas e morrotes com topos } \\
\text { alongados }\end{array}$ & 350 a $1100 \mathrm{~m}$ & $\begin{array}{l}<6 \% \text { e } \\
6 \text { a } 12 \%\end{array}$ & Média & $\begin{array}{l}\text { Basaltos com intercalados por arenitos intertrapeanos finos a médios } \\
\text { (Formação Serra Geral) }\end{array}$ & Nitossolos \\
\hline 2.3.6 Planalto do Foz de Areia & $\begin{array}{l}\text { Colinas e morrotes com topos } \\
\text { alongados }\end{array}$ & 400 a $1300 \mathrm{~m}$ & $\begin{array}{l}<6 \% \text { e } \\
12 \text { a } 30 \%\end{array}$ & Alta & $\begin{array}{l}\text { Basaltos com intercalados por arenitos intertrapeanos finos a médios } \\
\text { (Formação Serra Geral) }\end{array}$ & Neossolos \\
\hline $\begin{array}{l}\text { 2.3.7 Planalto do Médio } \\
\text { Paranapanema }\end{array}$ & Colinas com topos aplainados & 350 a $600 \mathrm{~m}$. & $<6 \%$ & Baixa & $\begin{array}{l}\text { Basaltos com intercalados por arenitos intertrapeanos finos a médios } \\
\text { (Formação Serra Geral) }\end{array}$ & $\begin{array}{l}\text { Latossolos e } \\
\text { Nitossolos }\end{array}$ \\
\hline $\begin{array}{l}\text { 2.3.8 Planalto Residual de } \\
\text { Botucatu }\end{array}$ & $\begin{array}{l}\text { Colinas com topos amplos } \\
\text { suavemente convexizados ou } \\
\text { aplainados }\end{array}$ & 600 a 900m. & 12 a $20 \%$ & Média & $\begin{array}{l}\text { Basaltos com intercalados por arenitos intertrapeanos finos a médios } \\
\text { (Formação Serra Geral) e Arenitos de granulação fina a grossa com } \\
\text { nódulos carbonáticos (Formação Marília) }\end{array}$ & $\begin{array}{l}\text { Latossolos e } \\
\text { Nitossolos }\end{array}$ \\
\hline 2.3.9 Planalto Residual de Marília & $\begin{array}{l}\text { Colinas com topos amplos } \\
\text { suavemente convexizados ou } \\
\text { aplainados }\end{array}$ & 500 a $600 \mathrm{~m}$. & 12 a $20 \%$ & Média & $\begin{array}{l}\text { Arenitos de granulação fina a grossa com nódulos carbonáticos } \\
\text { (Formação Marília) }\end{array}$ & $\begin{array}{l}\text { Argissolos e } \\
\text { Neossolos }\end{array}$ \\
\hline $\begin{array}{l}\text { 2.3.10 Planalto Centro Ocidental } \\
\text { Topos Tabulares }\end{array}$ & $\begin{array}{l}\text { Colinas amplas com topos } \\
\text { aplainados }\end{array}$ & 400 a $500 \mathrm{~m}$ & $\begin{array}{l}<6 \% \\
6 \text { a } 12 \% \\
\end{array}$ & Baixa & Arenitos finos a muito finos (Formação Vale do Rio do Peixe) & $\begin{array}{l}\text { Argissolos e } \\
\text { Latossolos }\end{array}$ \\
\hline $\begin{array}{l}\text { 2.3.11 Planalto Centro Ocidental } \\
\text { Topos Convexos }\end{array}$ & Colinas amplas com topos convexos & 350 a $550 \mathrm{~m}$ & 6 a $12 \%$ & Média & Arenitos finos a muito finos (Formação Presidente Prudente) & Argissolos \\
\hline \multicolumn{7}{|c|}{ UNIDADE MORFOESTRUTURAL BACIA SEDIMENTAR CENOZÓICA } \\
\hline \multicolumn{7}{|c|}{ UNIDADE MORFOESCULTURALPlanícies Fluviais } \\
\hline & \multicolumn{2}{|l|}{ Formas de Relevo } & \multicolumn{2}{|c|}{ Declividades dominantes } & Litologias dominantes & $\begin{array}{l}\text { Solos } \\
\text { dominantes }\end{array}$ \\
\hline 3.1 - Planícies Fluviais & \multicolumn{2}{|c|}{$\begin{array}{l}\text { Planícies de inundação e pequenos terraços } \\
\text { fluviais }\end{array}$} & \multicolumn{2}{|c|}{$<2 \%$} & Areias, cascalhos, siltes e argilas (Depósitos aluvionares Quaternários) & $\begin{array}{l}\text { Organossolos e } \\
\text { Neosolosflúvic } \\
\text { os }\end{array}$ \\
\hline
\end{tabular}

Fonte: Ross \&Moroz (1997); Santos et all (2006), IPT (1981) e Mineropar (2001) 
- subdivisão da unidade denominada Planalto Centro Ocidental (ROSS; MOROZ, 1997), distinguindo-se uma unidade com topos tabulares e fraca dissecação, outra unidade com topos convexos e média a forte dissecação, e a individualização do Planalto do Médio Paranapanema, adotando a mesma nomenclatura do Mapa Geomorfológico do Paraná, por se tratar de áreas homólogas e contínuas.

Tais subdivisões basearam-se nas informações morfológicas e morfométricas contidas no próprio Mapa Geomorfológico do Estado de São Paulo pois, embora os autores não tenham individualizado esses compartimentos como sub-unidades, eles foram identificados, delimitados e descritos na legenda e no memorial descritivo do Mapa Geomorfológico de Ross e Moroz (1997).Procedeu-se ainda, para a validação das informações, a análise e interpretação do MDE com resolução de 30 metros e ainda, a checagem das informações no mosaico semi-controladodo Radambrasil, em escala 1:250.000 (Folhas SF 22 -Y-A, SF 22- Y-B e SF 22- Z-A).

O mesmo raciocínio e os mesmos critérios foram adotados ao subdividir a unidade denominada Depressão do Paranapanema (ROSS; MOROZ, 1997), distinguindo-se uma unidade com topos tabulares e fraca dissecação e outra unidade com topos convexos e média a forte dissecação.

Outro ajuste efetuado refere-se a uma pequena área localizada na porção sudoeste do estado de São Paulo abrangendo parte dos municípios de Itararé e Itapeva que, de acordo com o mapa geomorfológico de Ross eMoroz (1997) pertence à sub-unidade Planalto de Guapiara (Unidade Morfoestrutural do Cinturão Orogênico do Atlântico). Em função das características morfológicas, morfométricas e, sobretudo morfogenéticas e litológicas, optou-se por incorporá-la à unidade definida por Oka-Fiori et al. (2006) como Planalto de São Luiz do Purunã (Unidade Morfoestrutural da Bacia Sedimentar do Paraná). Também nesse caso, as informações foram validadas a partir da análise e interpretação do MDE e imagem analógica do Radambrasil, além de análise de mapas geológicos.

\section{A Geomorfologia da Bacia Hidrográfica do Rio Paranapanema}

De acordo com as primeiras propostas de compartimentação do relevo do Estado de São Paulo (ALMEIDA, 1964) e do Estado do Paraná (MAACK, 1947), a Bacia Hidrográfica do Rio Paranapanema localiza-se nos seguintes compartimentos geomorfológicos: Planalto 
Atlântico (SP) e Primeiro Planalto (PR), que correspondem aos terrenos cristalinos; e, Depressão Periférica (SP) e Segundo Planalto (PR) e, Planalto Ocidental (SP) e Terceiro Planalto (PR), que correspondem aos terrenos da Bacia Sedimentar do Paraná. Essas nomenclaturas foram mantidas tanto no Mapa Geomorfológico do Estado de São Paulo (ROSS; MOROZ, 1997) quanto no Mapa Geomorfológico do Estado do Paraná (OKA-FIORI et al., 2006; SANTOS et al., 2006).

De acordo com Ross eMoroz (1997) o Rio Paranapanema tem suas nascentes nos terrenos cristalinos da Unidade Morfoestrutural Cinturão Orogênico do Atlântico, cuja morfoescultura denomina-se, genericamente, Planalto Atlântico.

Segundo RosseMoroz (1997) as morfoestruturas denominadas Cinturões Orogênicos, representadas pelas faixas dos dobramentos ocorridos no pré-Cambriano Médio e Superior, responsáveis pelas suturas das Plataformas ou Crátons, são dotadas de características estruturais, genéticas, idades e macro-morfologias específicas, destacando-se grandes variações altimétricas, paralelismo de serras e vales, intrusões ígneas associadas aos processos de dobramentos, e, apesar das longas fases erosivas, ainda guardam características de cadeias orogênicas.

O Cinturão Orogênico do Atlântico "é constituído, em suas zonas mais internas de grande variedade de gnaisses, que envolvem um cinturão central de complexos graníticos, ladeados por rochas metamorfoseadas no limite extremo do metamorfismo regional" (LOCZY; LADEIRA, 1976 apud ROSS; MOROZ. 1997).

A morfoescultura Planalto Atlântico corresponde a relevos sustentados por litologias diversas, sobretudo por rochas metamórficas associadas a rochas intrusivas. $\mathrm{O}$ modelado dominante é caracterizado por formas de topos convexos, elevada densidade de drenagem e vales profundos. (ROSS; MOROZ. 1997).

De acordo com Oka-Fiori et al. (2006), devido à diversidade de tipos litológicos e padrões estruturais marcados pela superposição de diversos ciclos geotectônicos e erosivos pré e pós-cretácicos, pode-se identificar no Planalto Atlântico variações fisionômicas regionais, que possibilitaram delimitar unidades geomorfológicas distintas. Desse modo, na porção paranaense da bacia hidrográfica do Rio Paranapanema, o Planalto Atlântico corresponde ao Primeiro Planalto Paranaense, sendo subdividido em Planalto de Castro e Planalto do Alto Jaguariaíva, enquanto que, na porção paulista, subdivide-se em Planalto de Guapiara e Planalto de Ibiúna/São Roque. 
CONTRIBUIÇÃO AO PLANEJAMENTO DE RECURSOS HÍDRICOS EM BACIA HIDROGRÁFICA: GEOMORFOLOGIA E FRAGILIDADE GEOAMBIENTAL DA UGRH PARANAPANEMA Isabel Cristina Moroz-Caccia Gouveia, Antonio Cezar Leal, Letícia Roberta Trombeta, Rafael da Silva Nunes e Vinícius BonafinStoqui

Segundo Oka-Fiori et al.(2006) a unidade denominada Primeiro Planalto Paranaense é relativamente uniforme, esculpida em rochas cristalinas, tais como xistos metamórficos e gnaisses, cortados por diques de pegmatitos e intrusões graníticas, com altitudes médias entre $850 \mathrm{~m}$ a $950 \mathrm{~m}$, formando uma paisagem suavemente ondulada. O Planalto de Castro, cujas altimetrias variam de $900 \mathrm{~m}$ a $1300 \mathrm{~m}$, e declividades predominantes estão abaixo de $6 \%$ e, secundariamente, entre $6 \%$ a $30 \%$, caracteriza-se por modelado de média dissecação, constituído por morros altos com topos alongados e aplainados e vales abertos de fundo chato. Já no Planalto do Alto Jaguarialva, as altimetrias variam de $800 \mathrm{~m}$ a $1300 \mathrm{~m}$ e as declividades predominantes estão abaixo de $6 \%$ e secundariamente entre 12 a 30\%. Esta unidade apresenta dissecação alta, com modelado constituído por morros baixos a médios, com topos alongados e vales em $\mathrm{v}$.

O Planalto de Guapiara caracteriza-se por um modelado constituído basicamente por morros médios com topos convexos, com dissecação média a alta. A litologia é constituída basicamente por filitos, granitos e calcários. As altimetrias variam de $700 \mathrm{~m}$ a $800 \mathrm{~m}$ e as declividades predominantes situam-se entre $20 \%$ a $30 \%$. A drenagem, nesta unidade de relevo, apresenta padrão dendrítico, de densidade média a alta. (ROSS; MOROZ. 1997).

Em estudos detalhados nas áreas de cabeceiras do Rio Paranapanema, Rodrigues, Moroze Santana (2008) identificaram drenagens de padrão anômalo, caracterizado pelo seu baixo grau de integração, ou seja, percursos contorcidos e orientação desorganizada, cuja densidade varia de média a alta. Face às características geomorfológicas do Planalto de Guapiara e à litologia constituída basicamente por mármores calcíticos, localmente bandeados por intercalações de filitos e meta-siltitos, os cursos d'água podem possuir trechos em superfície e trechos subterrâneos. Os vales, em geral, possuem entalhamento moderado, cujos canais fluviais apresentam perfis longitudinais de gradiente topográfico pouco elevado; ou ainda feições tipicamente fluviocársticas, caracterizadas por vales cegos, onde o fluxo aflora por uma ressurgência, flui em superfície e desaparece por sumidouros. As formas, nesta unidade, constituem-se basicamente por morros com topos convexos ou picos cônicos, além de dolinas que revelam feições características de exocarste. Essas feições, embora não apresentem grande desenvolvimento de cavernas e ressurgências, em função de menor amplitude topográfica entre canais subterrâneos, têm sua importância associada à sua singularidade fisionômica justamente por esse aspecto, que as distingue das 
demais formações cársticas existentes no Vale do Ribeira. São significativas, aí, formas como pequenos sumidouros, caneluras e cavernas de pequena dimensão.

Já o Planalto de Ibiúna/São Roque, apresenta modelado de dissecação média a alta, constituído por morros altos, com topos aguçados e topos convexos, sustentados por litologias representadas por migmatitos e granitos. As altimetrias variam de $800 \mathrm{~m}$ a $1.100 \mathrm{~m}$ e as declividades predominantes situam-se acima de $20 \%$, não sendo raras as áreas com declividades de $30 \%$. A drenagem, de alta densidade, em geral apresenta padrão dendrítico, com trechos claramente subordinados à estrutura. (ROSS; MOROZ. 1997).

Após percorrer inicialmente os terrenos cristalinos, as águas da bacia hidrográfica do Rio Paranapanema passam a drenar os terrenos sedimentares, relativos à Morfoestrutura Bacia Sedimentar do Paraná.

De acordo com Loczye Ladeira (1976) apud Ross eMoroz (1997), o embasamento da Bacia Sedimentar do Paraná é constituído principalmente de rochas cristalinas pré-Cambrianas e, subordinadamente, por rochas eo-paleozóicasafossilíferas e encontra-se preenchido por sedimentos na maior parte continentais e alguns depósitos marinhos, datados do Siluriano Superior (Formação Furnas) até o Cretáceo (Grupo Bauru), além de lavas basálticas de idade mesozoica.

Segundo Ross (1985), os planaltos em Bacias Sedimentares são quase que inteiramente circundados por depressões periféricas ou marginais, apresentando nos contatos (planaltosdepressões) relevos escarpados caracterizados por frentes de cuesta única, como ocorre no Estado de São Paulo, ou desdobradas em duas frentes, como ocorre nos estados do Paraná e Santa Catarina, onde uma apresenta-se nos terrenos do Devoniano e outra nas formações vulcânicas do Jura-Cretáceo.

Segundo Ross eMoroz (1997), processos tectônicos, como a epirogenia cenozoica da Plataforma Sul-americana que afetou de forma desigual o continente e induziu o desencadeamento de novas fases erosivas longas, e processos climáticos que produziram alternância de períodos secos e úmidos, são responsáveis pela gênese de duas unidades morfoesculturais distintas. Tais unidades morfoesculturais são denominadas, no estado do Paraná, Segundo Planalto Paranaense e Terceiro Planalto Paranaense e correspondem, respectivamente, à Depressão Periférica Paulista e Planalto Ocidental Paulista, no estado de São Paulo. 
CONTRIBUIÇÃO AO PLANEJAMENTO DE RECURSOS HÍDRICOS EM BACIA HIDROGRÁFICA: GEOMORFOLOGIA E FRAGILIDADE GEOAMBIENTAL DA UGRH PARANAPANEMA Isabel Cristina Moroz-Caccia Gouveia, Antonio Cezar Leal, Letícia Roberta Trombeta, Rafael da Silva Nunes e Vinícius BonafinStoqui

Segundo Oka-Fiori et al. (2006), sobre a grande unidade morfoestrutural Bacia Sedimentar do Paraná, no território paranaense, pode-se distinguir duas subunidades morfoesculturais: a Zona de Denudação Periférica e a Zona de Capeamento Basáltico-Arenítico. A primeira está esculpida na faixa de rochas Paleozóicas e apresenta-se, no Paraná, como um planalto modelado em estruturas monoclinais, sub-horizontais, mergulhando para o oeste, denominado Segundo Planalto Paranaense. A Zona de Denudação Periférica tem seus limites entre a escarpa Devoniana, a leste, onde as altitudes médias de cimeira estão entre 1100m a $1200 \mathrm{~m}$ e, a oeste, com a escarpa arenito-basáltica (Serra Geral ou da Esperança) onde, em suas proximidades, as altitudes variam entre 350 e 560 metros. A Zona de Capeamento Basáltico-Arenítico corresponde ao grande derrame mesozóico de rochas eruptivas básicas que, no território paranaense, apresenta-se como o Terceiro Planalto Paranaense, ou Planalto Arenito-Basáltico e abrange cerca de 2/3 do território paranaense.

Na morfoescultura referente à Zona de Denudação Periférica que corresponde ao Segundo Planalto Paranaense e à Depressão Periférica Paulista, distinguem-se subunidades de planalto e depressões. Os 11 planaltos identificados apresentam grande diversidade quanto ao modelado, apresentando graus de dissecação que variam de baixo a alto. A Depressão do Paranapanema apresenta modelado constituído basicamente por colinas de topos convexos e tabulares, com altimetrias que variam de $600 \mathrm{~m}$ a $700 \mathrm{~m}$, declividades entre $10 \%$ a $20 \%$ e litologia constituída por arenitos (ROSS; MOROZ. 1997). Foi subdividida em duas unidades que se diferenciam pelo grau de dissecação (alto e médio/baixo).

Ainda no domínio morfostrutural da Bacia Sedimentar do Paraná identificou-se a morfoescultura denominada Terceiro Planalto Paranaense que constitui o prolongamento doPlanalto Ocidental Paulista. Esta unidade morfoescultural subdivide-se em 11 unidades de planaltos, na bacia hidrográfica do Rio Paranapanema.

Segundo Oka-Fiori et al. (2006), o Terceiro Planalto Paranaense desenvolve-se como um conjunto de relevos planálticos, com inclinação geral para oeste-noroeste e subdivididos pelos principais afluentes do Rio Paraná, atingindo altitudes médias de cimeira de $1100 \mathrm{~m}$ a $1250 \mathrm{~m}$, na Serra da Esperança, declinando para altitudes entre $220 \mathrm{~m}$ e $300 \mathrm{~m}$ na calha do Rio Paraná. De um modo geral, os planaltos delimitados nessa morfoescultura apresentam dissecação baixa a média e topos aplanados, salvo exceções como o Planalto de Apucarana e Planalto do Foz de Areia, que apresentam dissecação alta e topos alongados. 
De acordo com IPT (1981) apud Ross eMoroz (1997) o Planalto Ocidental Paulista situa-se essencialmente sobre rochas do Grupo Bauru, que é constituído por diversas formações predominantemente areníticas, em algumas regiões cimentadas por carbonatos de cálcio. No vale do rio Paranapanema é possível observar também a exposição de basaltos. Neste planalto pode-se identificar variações fisionômicas regionais que permitem a delimitação de unidades geomorfológicas distintas, dentre as quais se destacam o Planalto Centro Ocidental e os planaltos residuais de Botucatu e de Marília. O Planalto Centro Ocidental apresenta modelado de amplas e baixas colinas de topos convexos aplanados ou tabulares (o que permitiu sua subdivisão), constituindo-se em formas de baixa dissecação. O Planalto Residual de Botucatu corresponde ao reverso de cuesta no interflúvio Tietê/Paranapanema, sendo que o Planalto Residual de Marília corresponde a um prolongamento dele, desempenhando um vasto planalto de topo aplanado.

Embutida nas morfoestruturas Cinturões Orogênico do Atlântico e Bacia Sedimentar do Paraná,encontra-se a morfoestrutura denominada Bacias Sedimentares Cenozóicas, representada na área de estudo pelas planícies fluviais (unidades morfoescultural). As planícies fluviais ocorrem em áreas restritas, associadas aos depósitos à montante de níveis de base locais e regionais. São terrenos planos, de natureza sedimentar fluvial quaternária, geradas por processos de agradação. Encontram-se dispostas em áreas junto às margens dos rios e estão sujeitas às inundações periódicas. São formadas por sedimentos fluviais arenosos e argilosos inconsolidados. (ROSS; MOROZ, 1997). Na bacia hidrográfica do Rio Paranapanema, destaca-se a presença de trechos de planícies fluviais no curso inferior do Rio Paranapanema, à jusante da UHE de Rosana, no Rio Paraná, à jusante da UHE Porto Primavera e no baixo curso do Rio Santo Anastácio, no estado de São Paulo, e, ainda, no alto curso do Rio Tibagi, no estado do Paraná.

\section{A Fragilidade GeoambientaldaUGRHParanapanema em escala 1:650.000}

O Mapa de Fragilidade Geoambiental da UGRH Paranapanema (Figura 2) foi elaborado a partir os níveis de fragilidade potencial do relevo presentes no Mapa Geomorfológico do Estado de São Paulo, em escala 1:500.000 (ROSS; MOROZ, 1997) e Mapa de Vulnerabilidade Geoambiental do Estado do Paraná, em escala 1:650.000 (OKA-FIORlet al., 2007; SANTOSet al., 2007). 
Os dois produtos cartográficos foram elaborados de acordo com a mesma metodologia, definida no estudo da Análise Empírica da Fragilidade dos Ambientes Naturais e Antropizados propostopor Ross (1994), baseado em Tricart (1977), que sistematiza uma hierarquia nominal de fragilidade representada por valores ou pesos: muito fraca (peso 1), fraca (peso 2), média (peso 3), forte (peso 4) e muito forte (peso 5). De acordo com essa metodologia, a Fragilidade é obtida a partir da análise integrada das seguintes variáveis: relevo, solos, litologia, cobertura vegetal/uso das terras e pluviosidade.

Entretanto, a junção dos dois mapas necessitou de ajustes para a compatibilização das informações pelos seguintes motivos:

- oMapa Geomorfológico do Estado de São Paulo apresenta cinco níveis de fragilidade potencial (Muito Baixa, Baixa, Média, Alta e Muito Alta). No Mapa de Vulnerabilidade Geoambiental do Estado do Paraná, os autores optaram por utilizar apenas três classes de vulnerabilidade geoambiental: Baixa, que engloba os níveis de muito baixa e baixa fragilidade; Moderada, que corresponde ao nível de média fragilidade e Alta, que engloba os níveis de alta e muito alta fragilidade, baseando-se em Ross (1994). Segundo os autores, "a definição de três das classes de vulnerabilidade no presente estudo, visou diminuir a subjetividade na decisão de escolha das classes de muito baixa e baixa, muito alta e alta, além de melhor compatibilidade com a escala adotada." (SANTOSet al., 2006, p. 813)

- No Mapa Geomorfológico do Estado de São Paulo o parâmetro morfométrico utilizado para a avaliação da variável relevo foi o Índice de Dissecação do Relevo (resultante do grau de entalhamento dos vales e dimensão interfluvial média); enquanto que no Mapa de Vulnerabilidade Geoambiental do Paraná, utilizou-se como principal parâmetro morfométrico, as classes de declividade, o que implicou em polígonos de classes de vulnerabilidade muito pequenos, irregulares e fragmentados.

Diante do exposto, foram feitas as seguintes modificações:

- agrupamento dos níveis de fragilidade potencial Muito Baixa e Baixa em uma única categoria (Baixa) e agrupamento dos níveis de fragilidade Alta e Muito Alta em uma única categoria (Alta) presentes no Mapa Geomorfológico do Estado de São Paulo (ROSS; MOROZ, 1997); - classificação dos níveis de fragilidade por unidade geomorfológica, na porção do estado do Paraná, de acordo com tabela síntese apresentada em Santos et al. (2007).

Feitas às compatibilizações, foi possível estabelecer níveis de fragilidade potencial para as diversas unidades geomorfológicas identificadas, conforme segue no Quadro 1: 


\begin{tabular}{|c|c|c|}
\hline \multicolumn{3}{|c|}{$\begin{array}{r}\text { Quadro 2. Fragilidade Geoambiental da UGRH Paranapanema. } \\
\text { UNIDADE MORFOESTRUTURAL CINTURÃO OROGÊNICO DO ATLÂNTICO }\end{array}$} \\
\hline \multicolumn{3}{|c|}{ Unidades Morfoesculturais: Primeiro Planalto Paranaense /Planalto Atlântico } \\
\hline Unidade Geomorfológica & Fragilidade & Característica \\
\hline 1.1.1 Planalto de Castro & Baixa & Baixa fragilidade face aos processos erosivos. Possibilidade de recalques em fundações e edificações \\
\hline 1.1.2 Planalto do Alto Jaguariaíva & Média & Moderada fragilidade aos processos erosivos. \\
\hline 1.1.3 Planalto de Guapiara & Alta & Área sujeita a processos erosivos agressivos, com probabilidade de ocorrência e movimentos de massa e erosão linear com voçorocas \\
\hline 1.1.4 Planalto de Ibiúna/São Roque & Alta & Área sujeita a processos erosivos agressivos, com probabilidade de ocorrência e movimentos de massa e erosão linear com voçorocas \\
\hline \multicolumn{3}{|c|}{ UNIDADE MORFOESTRUTURAL BACIA SEDIMENTAR DO PARANÁ } \\
\hline \multicolumn{3}{|c|}{ Unidades Morfoesculturais: Segundo Planalto Paranaense/Depressão Periférica Paulista } \\
\hline Unidade Geomorfológica & Fragilidade & Característica \\
\hline 2.1.1 Planalto de Guatá & Média & Moderada fragilidade face aos processos erosivos. \\
\hline 2.1.2 Planalto de Ponta Grossa & Média & Moderada fragilidade face aos processos erosivos. \\
\hline 2.1.3 Planalto de Irati & Média & Moderada fragilidade face aos processos erosivos. \\
\hline 2.1.4 Planaltos Residuais da Formação Teresina & Média & Moderada fragilidade face aos processos erosivos. \\
\hline 2.1.5 Planalto de São Luiz do Purunã & Média & Moderada fragilidade face aos processos erosivos. \\
\hline 2.1.6 Planalto de Jaguariaíva & Média & $\begin{array}{l}\text { Moderada fragilidade face aos processos erosivos, mas com possibilidade de queda de blocos nos setores mais íngremes de } \\
\text { vertentes. }\end{array}$ \\
\hline 2.1.7 Planalto de Tibagi & Baixa & Baixa fragilidade face aos processos erosivos. \\
\hline 2.1.8 Planalto de Ortigueira & Alta & Alta fragilidade aos processos erosivos, com possibilidade de ocorrência de movimentos de massa e queda de blocos. \\
\hline 2.1.9 Planalto de Santo Antônio da Platina & Alta & Alta fragilidade aos processos erosivos, com possibilidade de ocorrência de movimentos de massa e queda de blocos. \\
\hline 2.1.10 Planalto do Médio Cinzas & Média & Moderada fragilidade face aos processos erosivos. \\
\hline 2.1.11 Planalto de Carlópolis & Média & Moderada fragilidade face aos processos erosivos, ocorrência de movimentos de massa e queda de blocos. \\
\hline 2.2.1 Depressão do Paranapanema Topos convexos & Média & Moderada fragilidade face aos processos erosivos. \\
\hline 2.2.2 Depressão do Paranapanema Topos tabulares & Baixa & Baixa fragilidade face aos processos erosivos. \\
\hline \multicolumn{3}{|c|}{ Unidades Morfoesculturais: Terceiro Planalto Paranaense/ Planalto Ocidental Paulista } \\
\hline Unidade Geomorfológica & Fragilidade & Característica \\
\hline 2.3.1 Planalto de Paranavaí & Média & Moderada fragilidade face aos processos erosivos. \\
\hline 2.3.2 Planalto de Umuarama & Alta & Alta fragilidade aos processos erosivos \\
\hline 2.3.3 Planalto de Maringá & Média & Moderada fragilidade face aos processos erosivos. \\
\hline 2.3.4 Planalto de Apucarana & Baixa & Baixa fragilidade face aos processos erosivos. \\
\hline 2.3.5 Planalto de Londrina & Baixa & Baixa fragilidade face aos processos erosivos. \\
\hline 2.3.6 Planalto do Foz de Areia & Alta & Alta fragilidade aos processos erosivos \\
\hline 2.3.7 Planalto do Médio Paranapanema & Baixa & Baixa fragilidade face aos processos erosivos. \\
\hline 2.3.8 Planalto Residual de Botucatu & Média & Baixa fragilidade aos processos erosivos nos topos, mas Alta nos setores mais inclinados das vertentes. \\
\hline 2.3.9 Planalto Residual de Marília & Média & Baixa fragilidade aos processos erosivos nos topos, mas Alta nos setores mais inclinados das vertentes. \\
\hline 2.3.10 Planalto Centro Ocidental Topos Tabulares & Média & $\begin{array}{l}\text { Fragilidade Média a processos erosivos nos setores aplainados dos topos, entretanto, face às características texturais dos solos, os } \\
\text { setores de vertentes mais inclinados são bastante suscetíveis à erosão linear. }\end{array}$ \\
\hline 2.3.11 Planalto Centro Ocidental Topos Convexos & Alta & $\begin{array}{l}\text { Fragilidade Média a processos erosivos nos setores aplainados dos topos, entretanto, face às características texturais dos solos, os } \\
\text { setores de vertentes mais inclinados são extremamente suscetíveis à erosão linear. }\end{array}$ \\
\hline \multicolumn{3}{|r|}{ UNIDADE MORFOESTRUTURAL BACIAS SEDIMENTARES CENOZÓICAS } \\
\hline UnidadeMorfoescultural/ Unidade Geomorfológica & Fragilidade & Característica \\
\hline 3.1 Planícies Fluviais & Alta & $\begin{array}{l}\text { Áreas sujeitas a inundações periódicas. Lençol freático pouco profundo. Alta susceptibilidade à poluição das águas subterrâneas. Por } \\
\text { constituírem-se em sedimentos inconsolidados são áreas sujeitas à acomodações. }\end{array}$ \\
\hline
\end{tabular}

Fonte: Ross eMoroz (1997);Oka-Fiori et al.(2007) e Santos et al. (2007) 


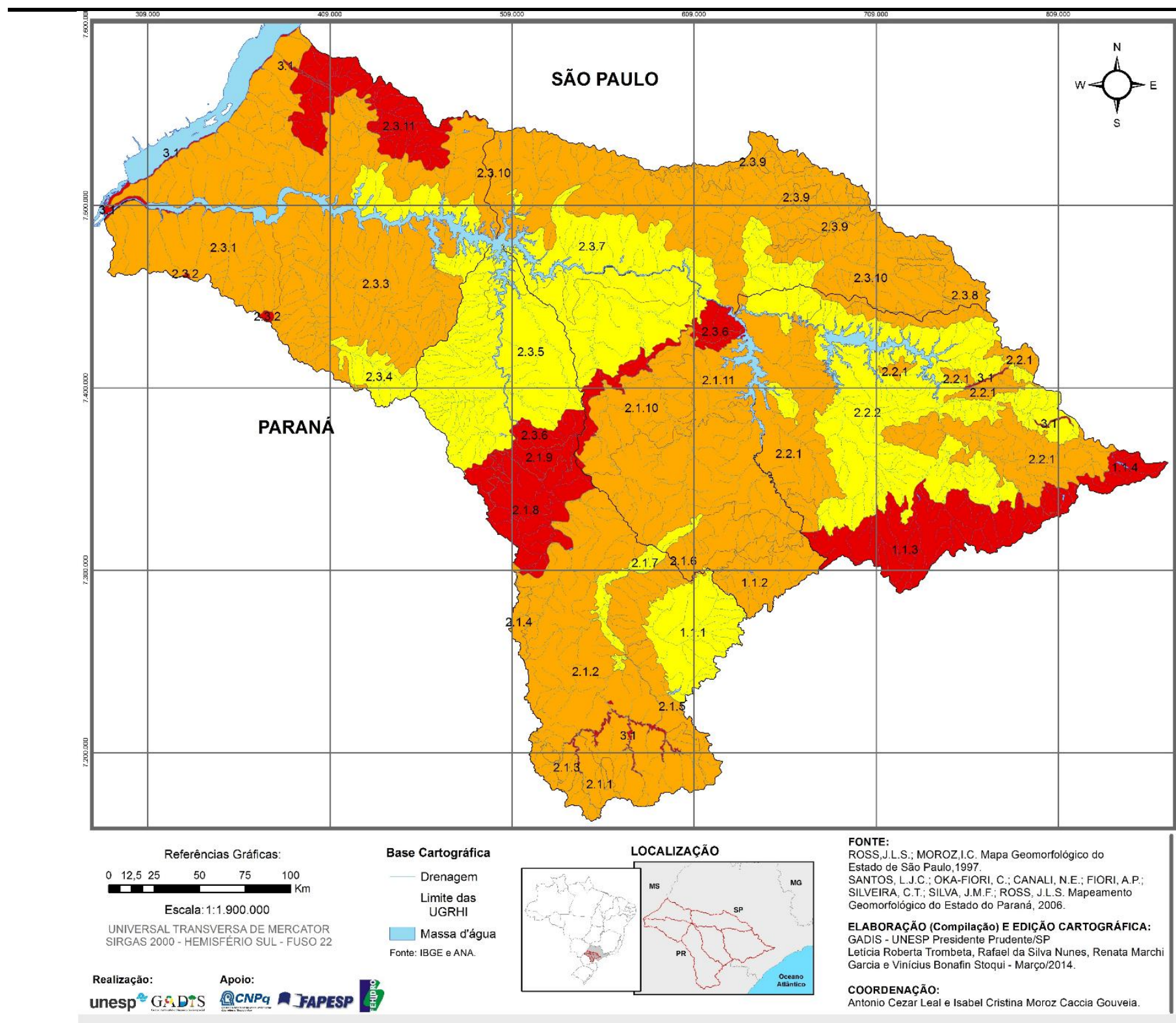

UGRH PARANAPANEMA

\section{LEGENDA}

FRAGILIDADE GEOAMBIENTAL

UNIDADE MORFOESTRUTURAL: CINTURÃO OROGÉNICO

UNIDADE MORFOESCULTURAL: PRIMEIRO PLANALTO

PARANAENSE PLANALTO ATLANTICOCO
Sub-unidades morfoesculturais:

Sub-unidades morfoescu
1.1.1. Planalto de Castro

1.1.2 Planalto do Alto Jaguariaiva

1.1.3. Planalto de Guapiara

UNIDADE MORFOESTRUTURAL: BACIA SEDIMENTAR

UNIDADE MORFOESCULTURAL: SEGUNDO PLANALTO

Sub-unidades morfoesculturais:

2.1.1 Planalto de Guatá

2.1.2 Planalto de Ponta Grossa

2.1.3 Planalto de Irat

Formação Teresina

2.1.5 Planalto de São Luiz do Purunã

2.1.6 Planalto de Jaguariaiva

2.1.9 Planalto de Santo Antônio da Platina

2.1 .10 Planalto do Médio Cinzas

UNIDADE MORFOESCULTURAL: DEPRESSÃo PERIFÉRICA

Sub-unidades morfoesculturais:

2.2.1 Depressão Paranapanema Topos Convexos

2.2.2 Depressão Paranapanema Topos Tabulares

UNIDADE MORFOESCULTURAL: TERCEIRO PLANALTO
PARANAENSE/ PLANALTO OCIDENTAL PAULISTA

Sub-unidades morfoesculturais:

2.3.1 Planalto de Paranavaí

2.3.2 Planalto de Umuarama

2.34 Planalto de Apucarana

2.3.5 Planalto de Londrina

2.3.6 Planalto do Foz de Areis

2.3.7 Planalto do Médio Paranapanem

2.3.8 Planalto Residual de Botucatu

2.3.9 Planalto Residual Marilia

2.3.10 Planalto Centro Ocidental Topos Tabulares
23.11
Planalto Centro Ocidental Topos Convexos

UNIDADE MORFOESTRUTURAL: BACIA SEDIMENTAR

UNIDADE MORFOESCULTURAL: PLANICIES FLUVIAIS

morfoesculturais:

enos terraços fluviais

FRAGILIDADE GEOAMBIENTAL

Figura 2 - Mapa de Fragilidade Geoambiental da UGRH Paranapanema 


\section{CONSIDERAÇÕES FINAIS}

Conforme pode ser observado, no caso da elaboração do Mapa Geomorfológico da UGRH Paranapanema, as modificações efetuadas não implicaram em generalizações. As informações contidas no Mapa Geomorfológico do Paraná foram integralmente mantidas e houve um maior detalhamento das unidades do Mapa Geomorfológico do Estado de São Paulo. Desse modo, o produto resultante da junção dos mapas pré-existente apresenta detalhamento compatível com a escala original deles (1:250.000).

Já o Mapa de Fragilidade Geoambiental da UGRH Paranapanema resultou em um produto cartográfico com maior grau de generalização que os documentos originais. Como o Mapa de Vulnerabilidade Geoambiental do Estado do Paraná (OKA-FIORlet al., 2007; SANTOS et al., 2007) apresenta apenas três níveis de fragilidade houve a necessidade, na porção paulista, de agrupar os cinco níveis de fragilidade potencial identificados por Ross eMoroz (1997). Também as informações contidas no Mapa de Vulnerabilidade Geoambiental do Estado do Paraná necessitaram de generalizações pois como os polígonos de níveis de vulnerabilidade se apresentam muito fragmentados, optou-se pela classificação da fragilidade por unidades geomorfológicas.

As descrições de incongruências identificadas na junção dos documentos cartográficos préexistentes, elaborados de acordo com a mesma metodologia porém com procedimentos técnicos diferentes, bem como o relato de critérios e procedimentos adotados para compatibilizar as informações disponíveis, evitando-se assim o árduo e longo trabalho de se produzir novos documentos cartográficos, exemplifica os desafios de natureza técnicocientíficos impostos aos estudos em bacias hidrográficas que envolvem mais de uma unidade federativa.

A experiência de criação do CBH-Paranapanema propiciou aos participantes do processo, em especial aos professores e estudantes, depararem-se com os desafios de construir a gestão compartilhada de águas com domínios da União e de Estados, neste caso, dos estados de São Paulo e do Paraná. Entre esses desafios, como demonstrado neste trabalho, está a unificação de estudos do meio físico e de documentos cartográficos, geralmente elaborados considerando-se recortes territoriais de atuação dos respectivos estados. 
Dessa forma, neste trabalho foram apresentados resultados que certamente contribuirão ao planejamento da UGRH Paranapanema, por meio da elaboração de mapas geomorfológicos e de fragilidade geoambiental, seguidos de descrição das respectivas unidades identificadas.

AGRADECIMENTOS: Ao CNPq (Proc. 473726/2010-6 e 309066/2009-3) e FAPESP (Proc. 2011/11827-8) pelo apoio ao desenvolvimento desta pesquisa.

\section{REFERÊNCIAS BIBLIOGRÁFICAS}

ALMEIDA, F. F. de Fundamentos Geológicos do Relevo Paulista. Bol. Inst. Geográfico e Geológico no 41, São Paulo, 1964.

BRASIL. CONSELHO NACIONAL DE RECURSOS HÍDRICOS. Resolução № 145, de 12 de dezembro de 2012.

BRASIL. CONSELHO NACIONAL DE RECURSOS HÍDRICOS. Resolução № 109, de 13 de abril de 2010.

BRASIL. CONSELHO NACIONAL DE RECURSOS HÍDRICOS. Resolução № 32, de 15 de outubro de 2003.

CHRISTOFOLETTI, A. Aplicabilidade do Conhecimento Geomorfológico nos Projetos de Planejamento. In: GUERRA, A. J. T. \& CUNHA, S. B. (1994) Geomorfologia: Uma atualização de bases e conceitos. Rio de Janeiro: Bertrand Brasil, 1994, p.415-441.

CREPANI, E.; MEDEIROS, J.S.; FILHO, P.H.; FLORENZANO, T.G.; DUARTE, V.; BARBOSA, C.C.F. Sensoriamento Remoto e Geoprocessamento aplicados ao zoneamento ecológico econômico e ao ordenamento territorial. Instituto de Pesquisas Espaciais - INPE. São José dos Campos - SP, 2001.

FLORENZANO, T. G. Avaliação de dados MSS-LANDSAT-4 para mapeamento geomorfológico no semi-árido como suporte ao planejamento regional: uma abordagem integrada (Área-teste: região de Juazeiro-BA) Dissertação de Mestrado, INPE, São José dos Campos, 1986. 
FLORENZANO, T. G. (org.). Geomorfologia: conceitos e tecnologias atuais. São Paulo: Oficina de Textos, 2008.

GIRÃO, O. \& CORRÊA, A. C. de B. A Contribuição da Geomorfologia para o planejamento da ocupação de novas áreas. In: Revista de Geografia. UFPE DCG/NAPA, v. 21, n. 2, jul/dez, Recife, 2004, p. 36-58

IPT - INSTITUTO DE PESQUISAS TECNOLÓGICAS DO ESTADO DE SÃO PAULO Mapa Geológico do Estado de São Paulo, escala 1:500.000. v1 (texto) e v2 (mapa). Governo do estado de São Paulo. Secretaria da Indústria, Comércio, Ciência e Tecnologia. IPT. São Paulo, 1981.

LEAL, A. C. Gestão das águas e planejamento ambiental na UGRH Paranapanema - Brasil: Estudos e Desafios. In: Geonorte, Edição Especial, V.4, N.4,2012, p.220 - 238

LOCZY, L. \& LADEIRA, E. A. Geologia estrutural e introdução à geotectônica. Ed. Edgar Blucher/CNDT, Rio de Janeiro, 1976.

MAACK, R. Breves notícias sobre a geologia dos estados do Paraná e de Santa Catarina. Arquivos de Biologia e Tecnologia, v. 2, Curitiba, 1947, p. 63-154.

MINEROPAR - MINERAIS, DO PARANÁ SA. Atlas geológico do Estado do Paraná. Curitiba: MINEROPAR, v. 1, 2001.

OKA-FIORI, C., SANTOS, L. J. C., CANALI, N. E., FIORI, A. P., SILVEIRA, C. T., SILVA, J. M. F., ROSS, J. L. S. Atlas Geomorfológico do Estado do Paraná: escala base 1:250.000, modelos reduzidos 1:650.000. MINEROPAR, Curitiba, 2006.

PROJETO RADAMBRASIL Folhas SF 22 -Y-A, SF 22- Y-B e SF 22- Z-A, mosaico semi-controlado de radar, em escala 1:250,000.Projeto Radambrasil, DNPM, 1976.

RODRIGUES, C. Geomorfologia Aplicada: Avaliação de experiências e de instrumentos de planejamento físico-territorial e ambiental brasileiros. (Tese de Doutorado, Departamento de Geografia, FFLCH-USP), São Paulo, 1997, 280p.

RODRIGUES, C; MOROZ, I. C. \& SANTANA, C. L. Geomorfologia Fluvial e Planejamento Ambiental no Meio Tropical Úmido: O exemplo do PEI - Parque Estadual Intervales/SP. In Anais do VII Simpósio Nacional de Geomorfologia, Belo Horizonte, 2008. 
ROSS, J. L. S. Ecogeografia do Brasil: subsídios para o planejamento ambiental. Oficina de Textos, São Paulo, 2006.

ROSS, J. L. S. Análises e Sínteses na Abordagem Geográfica do Planejamento Ambiental. Revista do Departamento de Geografia (USP), v. 09, São Paulo, 1996.

ROSS, J. L. S. Análise Empírica da Fragilidade dos Ambientes Naturais e Antropizados. Revista do Departamento de Geografia (USP), v. 08, São Paulo, 1994.

ROSS, J. L. S. O Registro Cartográfico dos Fatos Geomórficos e a Questão da Taxonomia do Relevo. Revista do Departamento de Geografia (USP), v. 06, São Paulo,1992.

ROSS, J. L.S. Relevo brasileiro: uma nova proposta de classificação. Revista do Departamento de Geografia (USP), v 4, São Paulo, 1985.

ROSS, J. L. S. \& MOROZ, I. C. Mapa Geomorfológico do estado de São Paulo escala 1:500.000.São Paulo: Laboratório de Geomorfologia, Departamento de Geografia FFLCH USP/IPT/FAPESP, 1997, vols. I e II.

SANTOS, L. J. C., OKA-FIORI, C., CANALI, N. E., FIORI A. P., SILVEIRA, C. T., FRANÇA DA SILVA, J. M. Mapeamento de Vulnerabilidade Geoambiental do Estado do Paraná. Revista Brasileira de Geociências, v.37, n. 4, São Paulo, 2007, p. 812-820

SANTOS, L. J. C.; OKA-FIORI, C.; CANALI, N.E.; FIORI, A. P.; SILVEIRA, C. T.; SILVA, J.M. F. \& ROSS, J. L. S. Mapeamento geomorfológico do Estado do Paraná. Revista Brasileira de Geomorfologia - Ano 7, n², São Paulo, 2006.

SÃO PAULO (Estado). Conselho Estadual de Recursos Hídricos (CRH). Deliberação CRH № 146, de 11 de dezembro de 2012.

SÃO PAULO (Estado) e PARANÁ (Estado). Caracterização Geral da UGRH Paranapanema. Volume 2, 2010.

SUGUIO, K. A Importância da Geomorfologia em Geociências e Áreas Afins. In Revista Brasileira de Geomorfologia, vol. 1, n. 1. São Paulo, 2000, p.80-87.

TRICART, J. Ecodinâmica. FIBGE/Supren, Rio de Janeiro, 1977. 97p. 
Artigo aceito em 09/03/2014. 